\title{
Homesickness and Displacement in Arab American Poetry
}

\author{
Wafa Yousef Alkahtib ${ }^{1}$ \\ ${ }^{1}$ Language Center, University of Jordan, Amman, Jordan \\ Correspondence: Wafa Yousef Alkahtib, Language Center, University of Jordan, Amman, Jordan. E-mail: \\ wafakhatib@yahoo.com
}

Received: December 1, 2018

Accepted: January 27, 2019

Online Published: February 28, 2019

doi:10.5539/mas.v13n3p165

URL: https://doi.org/10.5539/mas.v13n3p165

\begin{abstract}
The aim of this study is to address the nostalgic elements found in the Writings of the Arab American poet Naomi Shihab Nye. Nye is an American Palestinian poet whose works are mainly concerned with revealing her father's homesickness and detailing his lomging for his homeland and childhood memories.

The study makes an attempt to prove that the overwhelming nostalgia bonds the person with his lost homeland, and prevents him from forgetting his past; therefore' these feelings stand as a barrier between him and his new world. Displacement and homesickness are the main elements that increased the nostalgia of the immigrants for their homelands. To emphasize this, the current paper analysed some of Nye's poems which handle the sever nostalgia that Nye's father started suffering since the early beginning of his arrival to San Antonio, Texas in the United States of America.

Besides, the study argues that the nostalgic feeling for the homeland has been transmitted from father to son/ daughter, although the later doesn't have any memories in his/ her ex- homeland. Thus, Nye herself started feeling the nostalgia for a past she has never lived and to a homeland she has never seen.
\end{abstract}

Keywords: homesickness, nostalgia, past, displacement

\section{Introduction}

The concept of place is considered as one of the most familiar phenomena in our modern life. The feeling of displacement and dispossession spread among people in different parts of the world due to the revolutions that broke out in many countries. Immigrants from different parts of the world were compelled to seek refuge in different countries, suffering from severe bad conditions that increased their sense of displacement and nostalgia.

Place and memory are two factors that cannot be separated from each other; therefore, the longing for the past relied heavily on the place itself. No one can separate the place that he was born in from the memories of his childhood that he carries with him. Nostalgia or (Alhaneen in Arabic) is the happiest memories coated with melancholy. More tellingly, it is the feeling of loss, a combination of happy and sad memories, that keep pushing the person to look back to his precious past with deep emotions, and to protect the treasury of memories carried with him the moment he left his homeland.

Nomi Shihab Nye is an American Palestinian poet whose works are concerned mainly with her father's past and her Palestinian origin. Nye, who is daughter of a Palestinian Muslim father, Christian mother, is one of the most widely known Arab American writers.

This article aims to discuss the lives of immigrants in the United States, especially Palestinian immigrants who were enforced by the imperial powers to leave their own countries and to start their new life in a new land. The current paper tries to show how the collective trauma that all of the Palestinians passed through in the Diaspora increased their sense of displacement. The article also explains that this sense of displacement prevented those immigrants from leading a normal life away from their homeland, enhancing their longing for their past life.

For this purpose, some of Naomi Shihab Nye's poems have been selected to explain how this feeling of displacement and homesickness that her father and other immigrants suffered from clearly appeared in her writings, and how Nye tried to let the rest of the world know about her father's homesickness and alienation in a new place that he doesn't belong to.

Some researchers have tackled this issue in different scholarly works to investigate this critical issue of displacement and dispossession, in her article "The Middle Passage: Migration and Displacement of Srilankan 
Tamil Women of the Diaspora" Sivamohan Sumathy explains how the Tamil women and away from the homelands have succeeded to make sense of their existence in a new place and to keep in touch at the same time with their homelands.

In her thesis "Unveiling (His) tories: colonial dispossession in Emil Habiby's The Pessoetimist and Caryl Phillips Crossing the River" Mushira Salah Aldeen Sabri examined the dispossession in two colonial novels, and explained how they creatively exposed the ideological hierarchy that perpetuates dispossession, and how it affects both the oppressor and the oppressed.

This paper intends to examine Nye's ability to reveal how the sense of displacement and homesickness increase the person's longing for his past, especially if this person is cut off from his homeland by force. While some immigrants have succeeded in overcoming these feelings and coping with their new societies and creating themselves new identities, others couldn't overcome their trauma, leading them to fail to cope with the new culture. Those people are overwhelmed by their sorrows and nostalgia as Nye's father was one of the Palestinian immigrants who couldn't cope with the new culture in a new world.

\section{Analysis}

In all of Naomi Shihab Nye's writings the reader can feel her concerns about her father's nostalgia for a homeland that she doesn't know. Nye is involved in her father's past and is keen to reflect his sense of displacement in her poetry. Although Nye has never been to Palestine before, the reader can notice her homesickness for a place that she has never seen.

Ellen McAteer the director of "The Poetry Trust" noted that the themes of Nye's poetry incorporate images of Palestinians as people, "whom the shadow of the olive tree" will not leave people conditioned to tension, conditioned out of a peaceful life. https://www.arabamerica.com/palestinian-poet-naomi-shihab-nye-to-headlinemajor-british-arts-festival/

In her poems, Nye talks about her father who came to the United States as a college student in 1948. Now, he is 74 years old and couldn't overcome the painful nostalgic feeling for his homeland. Nye places her father in her poems to tell a story from her father's childhood in Palestine. This helped Nye find her a place in her father's past and memories. Ian Richard\& Zahi Salhi's The Arab Diaspora Voices of an Anguished Scream, argue that "Naomi Shihab Nye's work is characterized by an interesting combination of curiosity and nostalgia accepted with acquiescence and understanding rather than with emphasis on the tragic, although she doesn't ignore the elements of suffering and longing" (P: 119).

In her poem "The Man Who Makes Brooms" Nye talks about the burden of memories that captured her father in the past. Nye says,

So you come with these maps in your head

and I come with voices chiding me to

"speak for my people"

And we march around like guardians of memories

New land was not a kind of new beginning for Nye's father, but it was a disturbing space where he could not adapt to be one of its members. Therefore, it increased the sense of nostalgia and yearning for the proud past of his homeland, as words like "guardians" and "memories" are an emphasis on the yearning and longing of the speaker for his lost homeland. It proves that the person insists to keeping his memories untouchable and in a safe place where no one can touch or erase. These feelings clarify that this person will never be able to cope with his new homeland.

In her poem "My Father and the Fig Tree", Nye says

Years passed,

We lived in many houses,

None had fig trees.

We had lima beans, zucchini, parsley, beets.

"Plant one!" my mother said.

but my father never did.

For words like "passed", is based on nostalgia and homesickness in which Nye's father wishes that time would never pass. "passed" according to him is filled with grief and passion for his lost childhood. When Nye says "we 
lived in many houses" shows the restlessness of her father. In exile, Nye's father couldn't find relief, because he belonged to nowhere and this explains why he kept moving from one house to another as if he is looking for something that he couldn't find. Thus, Nye's father continued moving from one house to another looking for certain memories and certain past that he couldn't find.

In the same poem, Nye says:

He tended garden half-heartedly,

forgot to water, let the okra get too big.

"What a dreamer he is.

Look how many things he starts and doesn't finish."

In this poem, Nye portrays a picture of her father's garden in the States. She argues that he has no feelings for his new garden. He couldn't feel it the way he used to, he couldn't even love it." he tended garden half-heartedly" and "forgot to water". These lines prove the sense of alienation that Nye's father suffers from. His nostalgia for his old garden, which is planted with fig trees, prevents him from accepting or loving the new one. According to the immigrant, fig trees resemble Palestine; therefore, a garden without a fig tree is not even a garden. Nye says "None had fig trees".

The departure of Nye's father from his homeland seems more painful than death. The sense of loss and nostalgia inhabited his soul in a way that prevented him from building any bridges between himself and the new world. Nye's mother tried to relief her husband from his nostalgic feelings, as Nye says:" Plant one "my mother said, but my father never did. Nye's father couldn't believe that he can substitute his real fig tree with a new one.

The online Merriam-Webster dictionary defines nostalgia as, "pleasure and sadness that is caused by remembering something from the past and wishing that you could experience it again". The term nostalgia, or the feeling of homesickness, has been derived from a Homeric term, "nostos" which means homecoming.

Same displacement happened with Ghassan Kanafani (the Palestinian novelist) who insisted after his departure from his homeland on keeping one orange from his backyard, and somewhere inside the tent at a Lebanese refugee camp he put that orange in front of his eyes to remind him with his lost homeland Java. The moment he looks at the orange; it takes him back beyond the borders to his place.

The sever dispossession that Nye's father suffered from imprisoned him inside his past, as he refused to let that past go. He couldn't believe that anyone can feel the same nostalgia for a country they have never seen or for a past they have never lived. Melancholy and hope, loneliness and alienation are mixed together to encourage him to continue his quest for his lost homeland. Nye proves this by saying, "he watered garden half-heartedly" "Forgot to water" and "Let the Okra get too big".

In his book Nostalgia and Alienation in Arabic Poetry, Yahia Aljbouri explains that nostalgia is a human phenomenon, not restricted to any particular people or nation. Nostalgia is found in the soul of every human being, but one can say that this phenomenon is more obvious as the Arabic poetry has recorded it from the early stages of the Arabic history. Fig trees in Palestinian poetry were always linked to expatriation and nostalgia. They were always symbol of nostalgia and they motivate feelings of nostalgia in the person. (P: 1-2)

Nye's father tried to accept his new place, but he couldn't; he planted a new garden in the States, yet he has not been able to love it the same way he did with his old one. Nye considers her father a dreamer, she says, "what a dreamer he is". Nye's father kept dreaming about his homeland where he lived all of his happy childhood, and left all of his memories. Moreover, he tried to convince himself that he is still living there, and nothing has been changed. Although many years have passed, but Nye's fathercouldn't overcome his homesickness and wasn't able to plant himself in a different soil. Therefore, he tried to create his own new world which is similar to the world that he has left one day when he was forced to leave his homeland Palestine.

Nye says:

For other fruits, my father was indifferent

He'd point at the cherry trees and say

"See those? I wish they were figs."

His refusal to see the cherry trees are deliberately, because these trees resemble the new place that he refuses to accept, and a culture that he refuses to be part of; therefore, he insists on the idea that every cherry tree must be a fig tree. 
Nye's father is deeply indulged in the details of his happy past, where he imprisoned himself inside the fig tree which stands here as a symbol of his lost homeland. In The Uses of Nostalgia Laurence Learner raised questions about nostalgia, he argues "what are we longing for, in our nostalgia? Is it for a host of lost objects and lost experiences, or for one in particular that underlines them all? Are we longing for our lost childhood? Can we consider this nostalgia as a link with childhood that enabled him to survive? (P: 61) Learner "wonders about man's tendency to idealize the past. He continues, we don't need an ideal past to serve as a standard for judging the present. He argues that we all yearn nostalgically for childhood". (P: 245) This sense of nostalgia seems clear when Nye talks about her father, she says

In the evening he sat by my beds

weaving folktales like vivid little scarves

They always involved a fig tree.

Even when it didn't fit, he'd stick it in.

The content of all nostalgia is sorrow and yearning of the happy and sweet past evoked at times. Far or near, Nye's father is compelled to leave his homeland; his departure wasn't optional. Instaed, it was an exile, he has been cut off from his homeland and his place, and was sent to where he doesn't belong. These circumstances increased the nostalgic feelings, and helped him sink in the details of the past; therefore, he refused to accept the new culture or even to let others give him a hand to a new beginning. He tried to transmit all of his memories to his sons, so they can feel the same way as he does.

Notably, the fig tree according to Nye's father is a dream that he can touch with his bare hands, where he prefers to keep it as a dream. The fig tree doesn't belong here; it belongs there. If he plants a fig tree in the new land he will accept this land as a replacement of his homeland. Nye's father preferred to touch and to see his fig tree where it belongs; therefore, he refused to plant one in a different place.

Nye says,

But my father never did.

The happy past keeps the person that suffers from nostalgia in a good mode as long as he is able to build a bridge between his past and his present time, and between the place that he was born in and the new place where he lives. For Nye's father Arabic language is part of his lost homeland; therefore, Nye's father sings in Arabic language as an emphasis on his original identity that he refuses to change. The Arabic language sends him back to the place that he knows, and shortens the distance between past and present, and it satisfies his soul that suffers from loneliness and alienation. Nye says,

"My father, in Arabic, chanting a song".

Nye's father case proves that the refusal to adapt the new culture is a result of the suffering and suppression from the Israeli occupation. Palestinians were considered less assimilated than other Arab groups that immigrated to the States. And this appears clearly when Nye's father insists on drinking tea with mint and to use olive oil rather than butter. This also explains that Nye's father has failed to totally assimilate the new culture in which he lives.

An essay about Nye's grandmother home in Palestine "The Village", clarifies the nostalgic feelings. Nye says "The village smells familiar" she writes "whole scenes unfold like recent landscapes. However, the village not only affirms who she is, but also shows her how to listen to differences". (Suleiman, 1999, P:327) It smells familiar because Nye used to listen thousands of times to her father telling her about his village in Palestine, as he seemed all the time indulged in his past memories.

In his book Arabs in America Michael Suleiman asserts that "the challenges that Arab American have faced in their new homelands increased the sense of nostalgia and homesickness. Among the most important issues that faced them in the United States is the definition of who they are; their sense of identity as people, especially as they have continually encountered and continue to encounter bias and discrimination in their new homeland. Their new identities have been shaped by many factors but especially by continuing interactions between conditions in the old and new homelands and by the interplay between their perceptions of themselves and how others see them. (1999, p: 11-12)

For immigrants, nostalgia is a refuge that releases the person from his burdens and helps him to travel back to where he belongs. It is a safe place where he can collect all of his precious past memories in order to keep them alive, so he can transmit them to his sons and grandsons. This happens because, the immigrant feels that he is insecure and becomes afraid of not being able to go back to his childhood and to his home again. 
In her poem My Grandmother in the Stars, Nye says:

Heart saying

Take this home with you,

Never again,

And only memory making us rich. (69)

Nye says, I was born in the United States, but my father stared back toward the Middle East whenever he stood outside. Our kitchen smelled like the Middle East - garlic and pine nuts sizzled in olive oil, fried eggplant and hot pita bread. My father dropped sprigs of mint into our pots of hot tea. Nye's father wanted to share all of his pat memories with his family, and this helped Nye creates her image about a land she has never visited.

\section{Conclusion}

In a nutshell, the current paper concluded that Nye relies heavily on her father's memory as a space that enables her to travel with him to his past. Nye asserts in her poems that the Arab Americans who live in the States were afraid from forgetting their homelands, and their sense of fear increased day by day. Therefore, they tried to hold tightly on their memories and to keep them live by telling everybody about their previous golden days. The sense of fear turned to be part of their personalities and reflected in many literary works that have dealt with this problem.

Interestingly, the paper revealed the feeling of displacement and dispossession were the obstacles that stood between Nye's father and his new place. Until Nye's father recognizes himself as a part of the new culture and the new place, he will never be able to create himself a new identity or to be a part of the new culture. Although other immigrants from different parts of the world succeeded in creating themselves new identities, it is obvious clear that the Palestinians failed to create themselves new identities. This proves that the Palestinian people are convinced that one day they will go back to their homelands as long as they have the keys of their homes in Palestine.

\section{References}

Aljbouri, Y. (2008). Alhaneen Wa AlGorba Fi Alshear Alarabi. Jordan, Amman: Mjdalawi Publishers.

Lerner, L. (1972). The Uses of Nostalgia Studies in Pastoral Poetry. Great Braitin: Chattop and Windus ltd.

Nye, S. N. (1994). 19 Varieties of Gazelle. Library of Congress. United states of America.

Richard, I. N., \& Zahi, S., S. (2013). The Arab Diaspora Voices of N ANGUISHED Scream. United Kingdom, London: Routledge.

Sabri, M. S. (2013). Unveiling (His)tories: Colonial Dispossession in Emil Habiby's The Pessoeetimist and Caryl Phillip's Crossing the River. (Unpublished Master's thesis). The American University in Cairo, Cairo, Egypt.

Sivamohan S. (2005). The Middle Passage: Migration and Displacement of Srilankan Tamil Women of the Diaspora. Socio Legal Review11. National Law School of Indiana University.

Suleiman. W. M. (Ed.) (1999) Arabs in America.Temple University Press Philadelphia.: United States of America.

\section{Online Sources}

Ellen McAteer. Palestinian poet Naomi Shihab Nye to headline major British arts festival. (2015) https:/electronicintifada.net/blogs/sarah-irving/palestinian-poet-naomi-shihab-nye-headline-major-british-artsfestival

\section{Copyrights}

Copyright for this article is retained by the author(s), with first publication rights granted to the journal.

This is an open-access article distributed under the terms and conditions of the Creative Commons Attribution license (http://creativecommons.org/licenses/by/4.0/). 